\title{
LIPOPOLYSACCHARIDE ACCELERATES FINE PARTICULATE MATTER-INDUCED CELL APOPTOSIS IN HUMAN LUNG BRONCHIAL EPITHELIAL CELLS
}

\author{
QIN RU ${ }^{1,2}$, QI XIONG ${ }^{1,2}$, LIN CHEN $^{1,2}$, XIANG TIAN ${ }^{1,2}$, KAI YUE $^{1,2}$, BAOMIAO MA ${ }^{1,2}$, LU LIU ${ }^{1,2}$, \\ RIHUI WU ${ }^{1,2}$, CONGYUE XU ${ }^{1,2}$, MINGSHAN PI ${ }^{1}$, and CHAOYING LI',2
}

${ }^{1}$ Jianghan University, Wuhan, China

Wuhan Institutes of Biomedical Sciences

${ }^{2}$ Hanjea Biological Technology (Wuhan) Co., Ltd., Wuhan, China

Hanjea Institutes of Biomedical Sciences

\begin{abstract}
Objectives: The aim of the study has been to investigate the effect of the Standard Reference Material of fine particulate matter (SRM 2786) on cytotoxicity and apoptosis in human lung bronchial epithelial cells (16HBE cells). Whether the lipopolysaccharide (LPS)-induced inflammation could further accelerate cell apoptosis induced by SRM 2786 stimulation has also been determined. Material and Methods: 16HBE cells were exposed to various doses of SRM 2786 with or without LPS. The following parameters: cytotoxicity, apoptotic rate, Bax/Bcl-2 expression, nitric oxide (NO) production, and reactive oxygen species (ROS) generation were measured. Results: The results have shown that SRM 2786 induces cell damage and apoptosis of 16HBE cells as demonstrated by significant decrease in expression of Bcl- 2 and increase in expression of Bax. When compared with the control cells, the apoptotic rate of cells treated by $500 \mu \mathrm{g} / \mathrm{ml}$ of SRM 2786 increased from $2.43 \pm 0.21 \%$ to $43.96 \pm 2.95 \%$ ( $\mathrm{p}<0.01$ ). Further, there was an elevated production of NO and ROS post SRM 2786 treatment. The level of NO in cells treated with $500 \mu \mathrm{g} / \mathrm{ml}$ of SRM 2786 was $18.33 \pm 1.02 \mu \mathrm{mol} / \mathrm{l}$ whereas that of control cells was $1.58 \pm 0.31 \mu \mathrm{mol} / \mathrm{l}(\mathrm{p}<0.01)$. When compared with the control group, the level of intracellular ROS increased by $24 \%$ after treatment with $500 \mu \mathrm{g} / \mathrm{ml}$ of SRM $2786(\mathrm{p}<0.05)$. In addition, LPS pre-treatment may accelerate cell apoptosis by increasing generation of NO and ROS followed by SRM 2786 stimulation. When compared to cells treated with $125 \mu \mathrm{g} / \mathrm{ml}$ of SRM 2786 alone, the levels of NO and ROS in cells pretreated with LPS increased by $28 \%$ and $11.6 \%$, respectively $(\mathrm{p}<0.05$ ), and the apoptotic rate increased from $34.62 \pm 4.44 \%$ to $54.11 \pm 3.34 \%(\mathrm{p}<0.01)$. Conclusions: These findings have suggested that in vitro exposure to SRM 2786 could induce 16HBE cells apoptosis probably by means of the mechanism involving the generation of free radicals, while the degree of apoptosis would be further aggravated under inflammation condition. Int J Occup Med Environ Health 2018;31(2):173-183
\end{abstract}

Key words:

Apoptosis, Cytotoxicity, Inflammation, Fine particulate matter, Free radicals, Bronchial epithelial cells

Received: December 2, 2014. Accepted: December 4, 2016.

Corresponding author: C. Li, Jianghan University, Wuhan Institutes of Biomedical Sciences, Wuhan Economic and Technological Development Zone, Wuhan 430056, China (e-mail: licy.whibs.corresp@outlook.com). 


\section{INTRODUCTION}

Airborne particulate matters (PM) have recently gained specific attention as a main causative factor that contributes to increased incidence of adverse health outcomes, including respiratory diseases, cardiovascular diseases and systemic inflammation [1]. For instance, a 26-year survey has shown that each $10 \mu \mathrm{g} / \mathrm{m}^{3}$ increase in fine PM $\left(\mathrm{PM}_{2.5}\right)$ concentrations is associated with $15-27 \%$ increase in lung cancer mortality, especially for those with history of chronic lung disease [2]. Coarse $\mathrm{PM}\left(\mathrm{PM}_{10}\right)$ is also associated with increased chronic obstructive pulmonary disease hospitalizations, relative risk for cardiopulmonary and respiratory mortality $[3,4]$. Consequently, the underlying mechanisms of PM-induced adverse health effects are of intense scientific interest.

The airway epithelial cells are central to the defense of lung against exogenous substances, through the combined function of ciliated epithelial and secretory cells maintaining efficient mucociliary clearance [5]. Airway epithelial cells, especially bronchial epithelial cells, regulate both innate and adaptive immunity through production of functional molecules and physical interactions with cells of the immune system [6]. Therefore, the bronchial epithelial cells may be considered as a soldier in the fight against airborne PM.

Several studies have shown that PM could trigger epithelial cells damage [7]. For instance, $\mathrm{PM}_{2.5}$ could cause oxidative stress, resulting in activation of multiple cell death pathways in epithelial cells, including tumor necrosis factor $\alpha$ (TNF- $\alpha)$-induced extrinsic apoptotic pathway, the intrinsic apoptosis pathway, and autophagy pathway [8]. A mineral-rich $\mathrm{PM}_{10}$ sample causes cell toxicity and apoptosis in lung epithelial cells [9]. Notably, the capability of PM in inducing cell damage may diverse due to different locations and seasons. For instance, winter Milan $\mathrm{PM}_{25}$ induces a higher degree of DNA damage in comparison with summer $\mathrm{PM}_{25}$ [10]. Therefore, "standard" PM, which has been collected and analyzed by the National Institute of Standards and Technology (NIST) (Maryland, USA) is a reliable approach within PM research, as the size and chemical content of such reference materials have been well-characterized. The biological characterization of the Standard Reference Material 1648 for $\mathrm{PM}_{10}$ (SRM 1648) in epithelial cells has been reported [11], but the effect of SRM 2786 for fine PM on bronchial epithelial cell growth has not yet been evaluated.

The proliferation of bronchial epithelial cells has also been affected by various micro-environmental factors except direct damage caused by PM, including inflammation. Pro-inflammatory response could increase expression of cleaved caspase-3, and induce cell apoptosis in bronchial epithelial cells [12]. The inflammation triggered by lipopolysaccharide (LPS) could induce macrophages and epithelial cells apoptosis through Fas/FasLdependent pathway [13]. However, whether inflammation will further aggravate the cell apoptosis induced by PM has not been reported in the literature. Therefore, in this study, SRM 2786 has been used for assessing the effect of fine PM on cell viability and apoptosis in human lung bronchial epithelial cells (16HBE cells), and whether lipopolysaccharide (LPS)-induced inflammation might further enhance PM mediated apoptosis has also been determined.

\section{MATERIAL AND METHODS}

\section{Chemicals}

Roswell Park Memorial Institute (RPMI)-1640 medium, phosphate buffer solution (PBS) and fetal bovine serum (FBS) were obtained from Life Technologies (Carlsbad, CA, USA). Hoechst 33342, propidium iodide (PI), 2',7'-dichlorofluorescin diacetate (DCFH-DA) and lipopolysaccharide (LPS) were products of the Sigma Chemical Corp (St Louis, MO, USA). Lactate dehydrogenase (LDH) cytotoxicity assay kit and nitric oxide (NO) assay Kit were obtained from Beyotime Institute of Biotechnology (Haimen, China). Bcl-2 ELISA kit and 
Bcl-2 assaciated X protein (Bax) ELISA kit were procured from Biosource International, Inc. (California, USA). SRM 2786 was obtained from the National Institute of Standards and Technology (NIST, Maryland, USA). The certificate of analysis for SRM 2786 used in this study is available online [14]. All other chemicals were of standard analytical grade.

\section{Cell culture}

Human bronchial epithelial cells (16HBE cells) were purchased from the American Type Culture Collection (ATCC, USA) and grown in RPMI-1640 medium supplemented with $10 \%$ FBS and $100 \mathrm{U}$ penicillin/streptomycin in $5 \%$ carbon dioxide $\left(\mathrm{CO}_{2}\right)$ at $37^{\circ} \mathrm{C}$. Cells were passaged every 3 days and maintained at exponential growth to approximately $80 \%$ confluence for later experiments. All cell culture exposures were performed in 3 separate experiments.

\section{Preparation of SRM 2786 suspensions}

The SRM 2786 suspension was prepared just prior to usage. The stock solutions of particles were dispersed in RPMI-1640 medium at a concentration of $2000 \mu \mathrm{g} / \mathrm{ml}$ and then sonicated for 5 min under cooling conditions (Ningbo Scientz Biotechnology Co., Ltd., China).

\section{Exposure of cells to SRM 2786 and LPS}

Varied concentrations of SRM $2786(31.25 \mu \mathrm{g} / \mathrm{ml}$, $62.5 \mu \mathrm{g} / \mathrm{ml}, 125 \mu \mathrm{g} / \mathrm{ml}, 250 \mu \mathrm{g} / \mathrm{ml}$, or $500 \mu \mathrm{g} / \mathrm{ml}$ ) were then prepared in RPMI-1640 medium supplemented with $10 \% \mathrm{FBS}$ and $100 \mathrm{U}$ penicillin/streptomycin, and vigorously vortexed for 2 min prior to each experiment according to a previously published study [11]. Human lung bronchial epithelial cells (16HBE) were incubated with varied concentrations of SRM 2786 for $24 \mathrm{~h}$.

In LPS pretreatment experiments, LPS $(0.1 \mu \mathrm{g} / \mathrm{ml})$ was prepared in sterile PBS. Cultured cells were divided into 8 group, cells of 4 groups were pretreated with LPS for $18 \mathrm{~h}$ according to a previous study [15]. After $18 \mathrm{~h}$, the supernatants of all wells were removed and then replaced with varied concentrations of SRM 2786 suspension for another $24 \mathrm{~h}$ incubation.

\section{Lactate dehydrogenase (LDH) cytotoxicity assay}

The degree of cytotoxicity was determined by LDH activities of supernatant. Briefly, cells were seeded at 5000 cells/ well into a 96-well plate and incubated overnight. After being treated with varied concentrations of test substance, supernatants of samples with varied treatments were transferred to a new 96-well plate as a measured group, meanwhile the control group, standard group and blank group were also prepared according to the manufacturer's instructions, and the reaction mixture from the kit was added. After incubation for $15 \mathrm{~min}$ at room temperature, optical density (OD) at $450 \mathrm{~nm}$ was recorded using a 96-well microplate reader (Thermo Scientific, USA). Lactate dehydrogenase activity was determined by the following computing formula:

$$
\begin{aligned}
& \text { LDH activity }(\mathrm{U} / \mathrm{l})=\frac{\text { OD measured }- \text { OD control }}{\text { OD standard }- \text { OD blank }} \times \\
& 0.2 \mathrm{mmol} / \mathrm{l} \text { (standard substance concentration }) \times 1000
\end{aligned}
$$

where:

LDH - lactate dehydrogenase, OD - optical density.

\section{Hoechst 33342/PI staining assay}

Hoechst 33342/PI staining assay was used for assessing cell apoptosis. Human lung bronchial epithelial cells (16HBE) were plated at an initial density of $1 \times 10^{5}$ cells/well into a 24-well plate and incubated overnight. After treatment with varied concentrations of test substance, cells were washed gently with PBS twice, and stained with Hoechst $33342(5 \mu \mathrm{g} / \mathrm{ml})$ at $4^{\circ} \mathrm{C}$ for $10 \mathrm{~min}$ without light. The cells were then stained with propidium iodide (PI) $(5 \mu \mathrm{g} / \mathrm{ml})$ in the dark for $10 \mathrm{~min}$ at $4^{\circ} \mathrm{C}$ and 
washed gently with PBS twice. Hoechst 33342 may readily pass through all cell membranes (blue stained), while PI can only penetrate into apoptotic cells (red stained), the positive staining with PI was indicative of apoptotic cells. Cells staining blue or red were examined under a fluorescence microscope (Olympus, Japan). The bluestained cells were consided to be as viable cells, while the red-stained cells were recognized as apoptotic cells. The apoptotic rate was determined by the following formula:

\footnotetext{
Apoptotic rate $(\%)=$ number of apoptotic cells

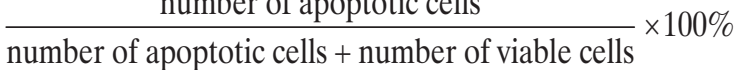

\section{Determination of the levels \\ of Bcl-2 and Bax by ELISA}

To further verify the effect of SRM 2786 on cell apoptosis, the levels of Bax (an apoptosis promoter) and Bcl-2 (an apoptosis inhibitor) were determined using ELISA kits. Firstly, 16HBE cells were plated at an initial density of $5 \times 10^{6}$ cells per flask into cell culture flasks, incubated overnight, and then treated by different test substances. After treatment, cells were harvested and washed with cold PBS twice. The sediments were re-suspended in $200 \mu \mathrm{l}$ cold PBS, sonicated for 2 min under cooling condition, and centrifuged at $16000 \mathrm{~g}$ at $4^{\circ} \mathrm{C}$ for $15 \mathrm{~min}$. Finally, the supernatants were carefully collected to analyze the protein expression of Bcl-2 or Bax by commercial available ELISA kits. The detailed experimental steps were conducted following manufacturer's instructions. The absorbance was measured by microplate reader at $450 \mathrm{~nm}$. The protein expressions of Bcl-2 and Bax in different groups were calculated based on corresponding standard curves.

\section{The production of NO}

Quantification of nitrite ions was applied as an indirect way to determine the production of NO. Briefly, 16HBE cells were plated at an initial density of $1 \times 10^{5}$ cells/well into a 24-well plate, incubated overnight, and exposed to varied concentrations of test substances. After treatment, the supernatants were collected to analyze the production of NO. The detailed experimental steps were conducted following manufacturer's instructions. The production of NO for each group was calculated according to a standard curve.

\section{Measurement of reactive oxygen species (ROS)}

Reactive oxygen species was measured by the fluorescent probe DCFH-DA. Human lung bronchial epithelial cells $(16 \mathrm{HBE})$ were plated at an initial density of $5 \times 10^{6}$ cells per flask into cultured flasks, incubated overnight, and then treated by different test substances. After treatment, cells were harvested and washed with cold PBS twice. The sediments were re-suspended in $500 \mu \mathrm{l}$ of $100 \mu \mathrm{mol} / \mathrm{l} \mathrm{DCFH}-\mathrm{DA}$ for $1 \mathrm{~h}$ in $\mathrm{CO}_{2}$ incubator. Then the DCFH-DA was removed and cells were washed with PBS twice. The fluorescence was evaluated by flow cytometer (Becton-Dickinson). The amount of ROS production was considered to be directly proportional to the fluorescence intensity. Results are shown as normalized fluorescence intensity of the control group [16].

\section{Statistical analysis}

Data was expressed as mean \pm standard deviation $(\mathrm{M} \pm \mathrm{SD})$. The statistical analysis was conducted using the SPSS 20.0. Levene's test was used for checking the homogeneity of variance. If equal variances are assumed, the significance of differences is determined by Tukey honest significant difference (HSD) post hoc test after one-way ANOVA. If equal variances are not assumed, the significance of differences is determined by independent samples Kruskal-Wallis test followed by all pairwise multiple comparisons. A value of $p$ less than 0.05 has been considered to be statistically significant. 

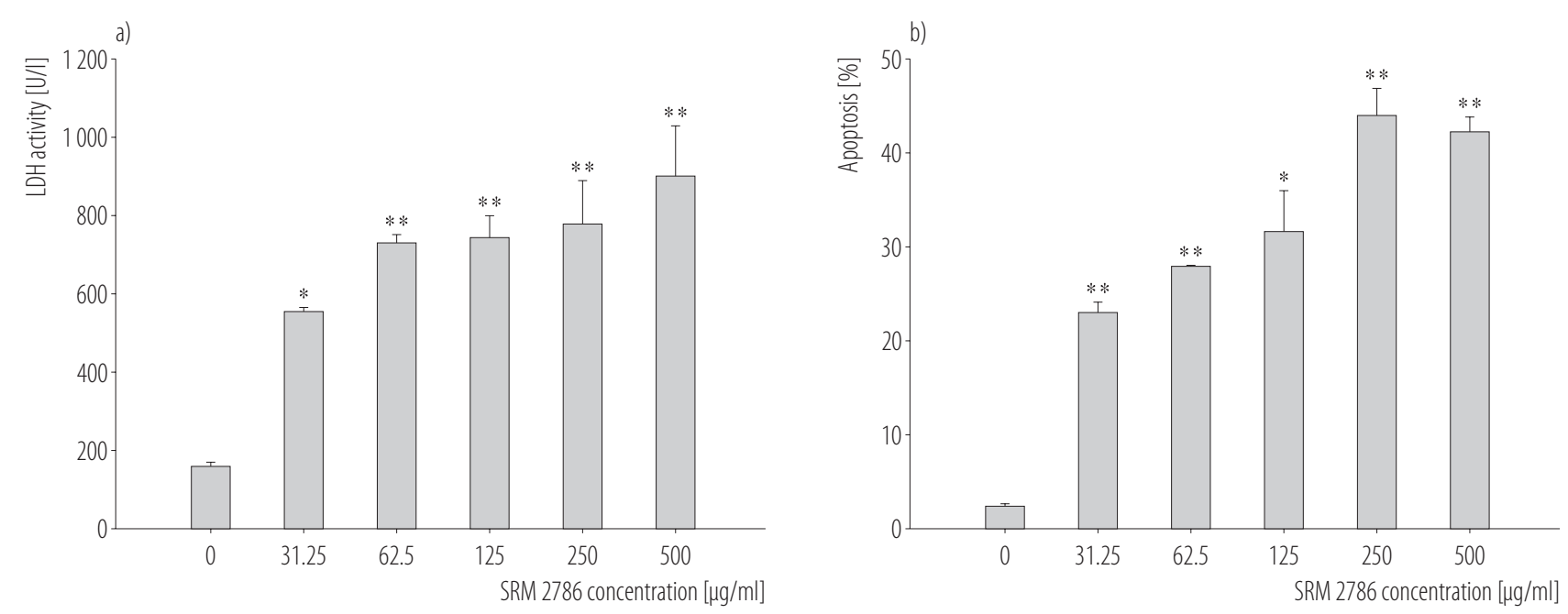

The values represent mean \pm standard deviation of 3 independent experiments.

${ }^{*} \mathrm{p}<0.05$ - compared to control cells; ${ }^{* *} \mathrm{p}<0.01$ - compared to control cells.

Fig. 1. Effect of standard reference material of fine particulate matter (SRM 2786) exposure on a) lactate dehydrogenase (LDH) activities and b) cell apoptosis in human lung bronchial epithelial (16HBE) cells

\section{RESULTS}

\section{Effect of SRM 2786}

\section{on the viability of $16 \mathrm{HBE}$ cells}

Lactate dehydrogenase cytotoxicity assay was used for measuring the effect of SRM 2786 on the viability of $16 \mathrm{HBE}$ cells (Figure 1a). When compared with the control group, the activities of $\mathrm{LDH}$ progressively increase by $363 \%, 476 \%, 485 \%, 506 \%$ and $589 \%$, respectively after incubation with $31.25 \mu \mathrm{g} / \mathrm{ml}, 62.5 \mu \mathrm{g} / \mathrm{ml}, 125 \mu \mathrm{g} / \mathrm{ml}$, $250 \mu \mathrm{g} / \mathrm{ml}$ or $500 \mu \mathrm{g} / \mathrm{ml}$ of SRM 2786 for $24 \mathrm{~h}$ ( $<<0.05)$.

\section{Effect of SRM 2786}

\section{on the apoptosis of $16 \mathrm{HBE}$ cells}

As illustrated in the Figure 1b, SRM 2786 significantly increases the percentage share of apoptotic cells at the dose of $31.25-500 \mu \mathrm{g} / \mathrm{ml}(\mathrm{p}<0.05)$. The apoptotic rate of control cells was $2.43 \pm 0.21 \%$, while the apoptotic rates of $16 \mathrm{HBE}$ cells treated with $31.25 \mu \mathrm{g} / \mathrm{ml}$, $62.5 \mu \mathrm{g} / \mathrm{ml}, 125 \mu \mathrm{g} / \mathrm{ml}, 250 \mu \mathrm{g} / \mathrm{ml}$ or $500 \mu \mathrm{g} / \mathrm{ml}$ of SRM 2786 were $22.96 \pm 1.06 \%, 27.85 \pm 0.21 \%, 31.66 \pm 4.27 \%$, $43.96 \pm 2.95 \%$ and $42.17 \pm 1.67 \%$, respectively. As shown in the Figure 2, as compared with the control group, no significant changes in the expression of Bax were detected when the concentration of SRM 2786 was relatively low $(31.25-250 \mu \mathrm{g} / \mathrm{ml})$, but the level of Bax increased from $0.63 \pm 0.04 \mathrm{ng} / \mathrm{ml}$ to $0.93 \pm 0.12 \mathrm{ng} / \mathrm{ml}$ after having been treated with $500 \mu \mathrm{g} / \mathrm{ml}$ of SRM 2786 ( $<<0.05$ ). On the contrary, the expression of Bcl-2 significantly decreased from $25.39 \pm 1.06 \mathrm{ng} / \mathrm{ml}$ to $17.72 \pm 1.46 \mathrm{ng} / \mathrm{ml}$ after SRM 2786 treatment at the dose of $500 \mu \mathrm{g} / \mathrm{ml}$ $(\mathrm{p}<0.05)$.

\section{Effect of SRM 2786 on the production of NO and ROS}

The Figure 3a presents the NO responses to varied concentrations of SRM 2786. When compared to control cells without SRM 2786 treatment, all concentrations of SRM 2786 significantly increase NO production ( $p<0.01$ ). The levels of NO in supernatant of $16 \mathrm{HBE}$ cells treated with $31.25 \mu \mathrm{g} / \mathrm{ml}, 62.5 \mu \mathrm{g} / \mathrm{ml}$, $125 \mu \mathrm{g} / \mathrm{ml}, 250 \mu \mathrm{g} / \mathrm{ml}$ or $500 \mu \mathrm{g} / \mathrm{ml}$ of SRM 2786 were $12.08 \pm 0.36 \mu \mathrm{mol} / \mathrm{l}, 13.18 \pm 0.33 \mu \mathrm{mol} / \mathrm{l}, 15.08 \pm 1.45 \mu \mathrm{mol} / \mathrm{l}$, $16.08 \pm 0.17 \mu \mathrm{mol} / \mathrm{l}$ and $18.33 \pm 1.02 \mu \mathrm{mol} / \mathrm{l}$, respectively 

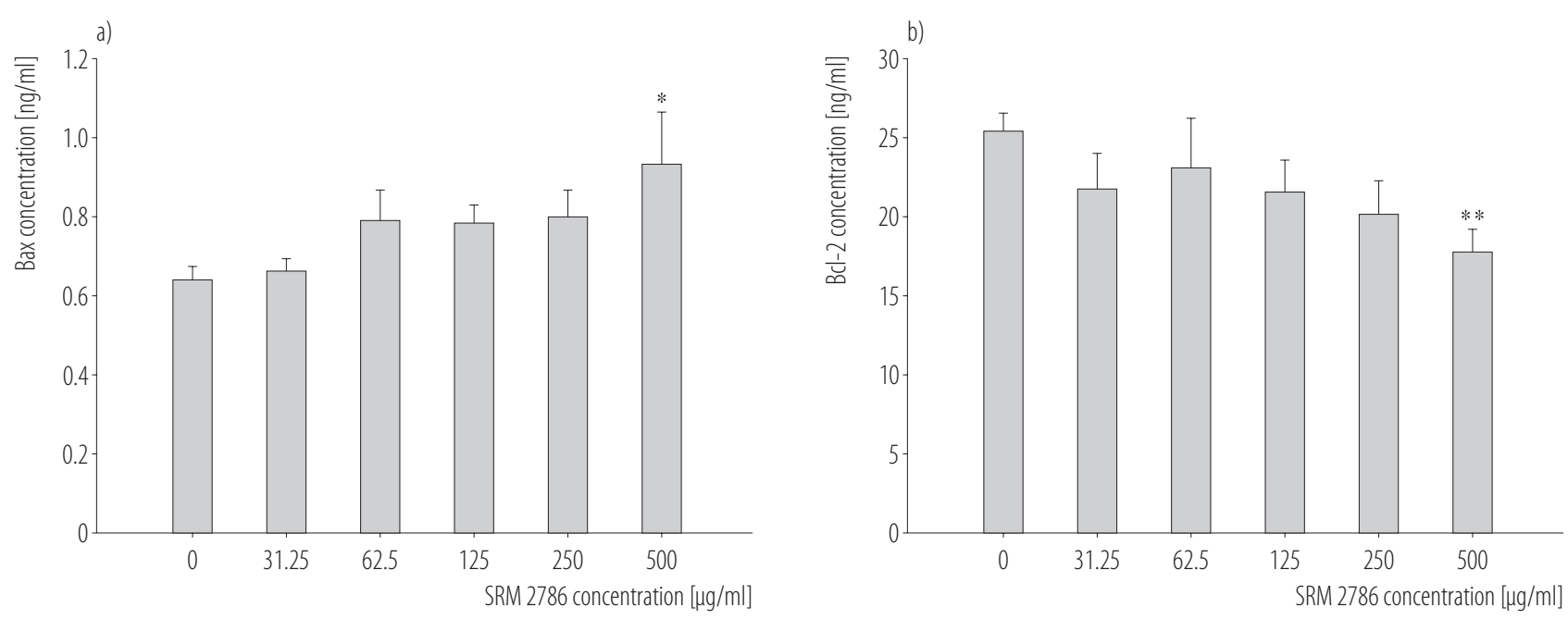

The values represent mean \pm standard deviation of 3 independent experiments.

${ }^{*} \mathrm{p}<0.05$ - compared to control cells; ${ }^{* *} \mathrm{p}<0.01$ - compared to control cells.

Fig. 2. Effect of standard reference material of fine particulate matter (SRM 2786) exposure on the expression of Bax and Bcl-2 in human lung bronchial epithelial (16HBE) cells
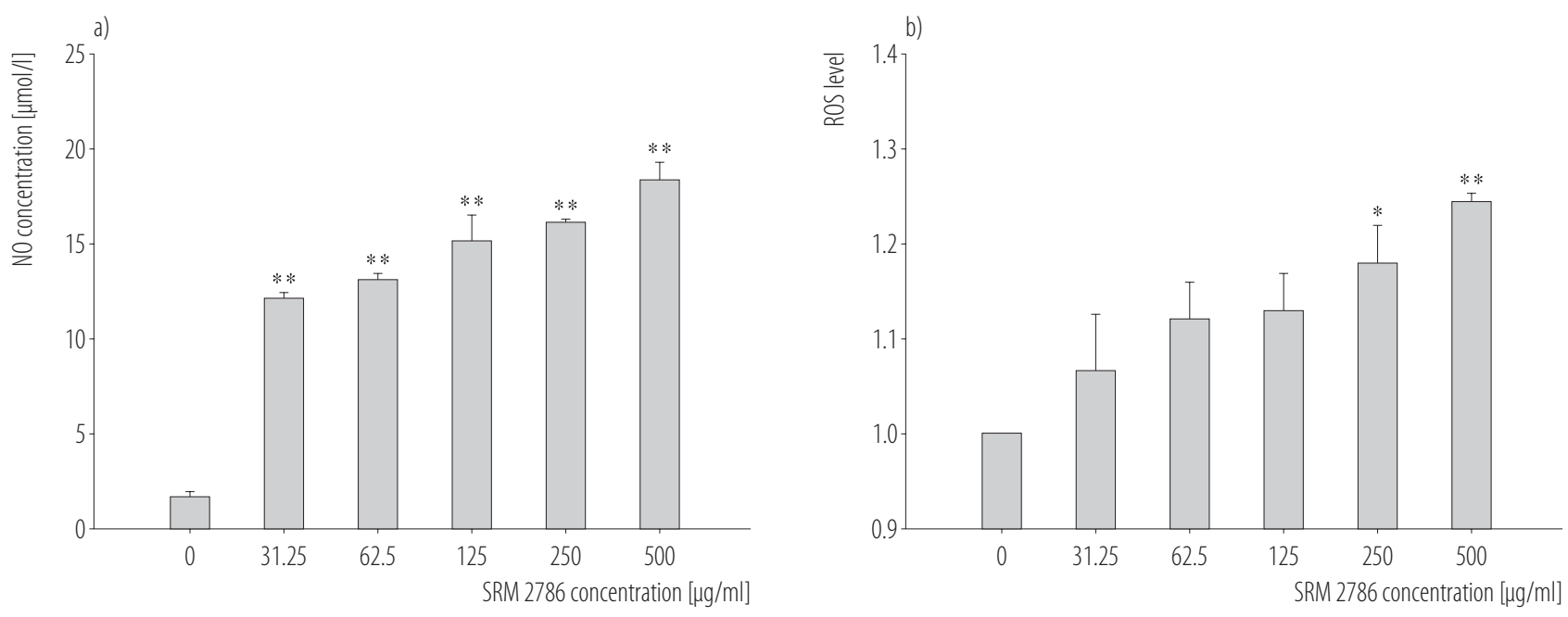

The values represent mean \pm standard deviation of 3 independent experiments.

Results of ROS are shown as normalized fluorescence intensity of control.

${ }^{*} \mathrm{p}<0.05$ - compared to control cells; ${ }^{* *} \mathrm{p}<0.01$ - compared to control cells.

Fig. 3. The production of nitric oxide (NO) and reactive oxygen species (ROS) induced by standard reference material of fine particulate matter (SRM 2786) in human lung bronchial epithelial (16HBE) cells

whereas NO content in supernatant of control cells was $1.58 \pm 0.31 \mu \mathrm{mol} / \mathrm{l}$.

The levels of intracellular ROS were measured using a DCFH-DA fluorescence assay. As shown in the Fig- ure $3 \mathrm{~b}$, as compared with the control group, the levels of intracellular ROS increase by $6.5 \%, 11.9 \%$, and $13.9 \%$ after treatment with $31.25 \mu \mathrm{g} / \mathrm{ml}, 62.5 \mu \mathrm{g} / \mathrm{ml}$ or $125 \mu \mathrm{g} / \mathrm{ml}$ of SRM 2786, while the level of intracellular ROS in- 
creases significantly by $18.9 \%$ and $24.4 \%$ after having been treated with $250 \mu \mathrm{g} / \mathrm{ml}$ or $500 \mu \mathrm{g} / \mathrm{ml}$ of SRM 2786 $(\mathrm{p}<0.05)$. These results suggest that SRM 2786 may exert its pro-apoptotic effect by modulating the production of NO and ROS in 16HBE cells.

\section{LPS accelerates SRM 2786-induced cell apoptosis in $16 \mathrm{HBE}$ cells}

To further examine the effects of LPS pretreatment on the SRM 2786-induced apoptosis of 16HBE cells, cells were pretreated with $0.1 \mu \mathrm{g} / \mathrm{ml}$ LPS for $18 \mathrm{~h}$ prior to exposure to varied concentrations of SRM2786.

The results of LDH cytotoxicity assay have indicated that in comparison with cells treated with SRM 2786 alone, significant increase in release of LDH is observed when cells are pretreated with LPS $(125 \mu \mathrm{g} / \mathrm{ml}$ of SRM 2786, increased by $56 \%, 500 \mu \mathrm{g} / \mathrm{ml}$ of SRM 2786 increase by $26.5 \%$, $\mathrm{p}<0.05)$ (Table 1). When compared to cells treated with SRM 2786 alone, the apoptotic rate of $16 \mathrm{HBE}$ cells is higher after LPS pretreatment ( $p<0.01)$. The apoptotic rates of $16 \mathrm{HBE}$ cells treated with $31.25 \mu \mathrm{g} / \mathrm{ml}, 125 \mu \mathrm{g} / \mathrm{ml}$ or $500 \mu \mathrm{g} / \mathrm{ml}$ of SRM 2786 are $17.87 \pm 1.33 \%, 34.62 \pm 4.44 \%$ and $43.05 \pm 0.65 \%$, respectively whereas the apoptotic rates of $16 \mathrm{HBE}$ cells pretreated with LPS are $43.28 \pm 4.43 \%$, $54.11 \pm 3.34 \%$ and $68.93 \pm 2.49 \%$, respectively.

Lipopolysaccharide pretreatment increases NO production without SRM 2786 stimulation, but there is no statistical difference as compared to control cells ( $p>0.05$ ). However, LPS pretreatment significantly increases NO production when cells are exposed to SRM 2786 at the concentration of $125 \mu \mathrm{g} / \mathrm{ml}$ or $500 \mu \mathrm{g} / \mathrm{ml}$. As demonstrated in the Table 2, the level of NO in supernatant of $16 \mathrm{HBE}$ cells pretreated with LPS is $22.83 \pm 0.55 \mu \mathrm{mol} / 1$ whereas that of cells treated with $500 \mu \mathrm{g} / \mathrm{ml}$ of SRM 2786 alone is $18.33 \pm 1.02 \mu \mathrm{mol} / \mathrm{l}$ $(\mathrm{p}<0.01)$. Moreover, pretreatment with LPS accelerates the production of ROS significantly when the doses of SRM 2786 are $31.25 \mu \mathrm{g} / \mathrm{ml}$ and $125 \mu \mathrm{g} / \mathrm{ml}$. After normalization of the control group, the levels of ROS in cells treated by both $125 \mu \mathrm{g} / \mathrm{ml}$ of SRM 2786 and LPS are $125 \pm 2 \%$ whereas that of cells treated by $125 \mu \mathrm{g} / \mathrm{ml}$ of SRM 2786 alone is $112 \pm 3 \%$ $(\mathrm{p}<0.05)$. Yet LPS alone does not alter ROS production in 16HBE cells significantly ( $p>0.05)$.

Table 1. Combined effects of standard reference material of fine particulate matter (SRM 2786) and lipopolysaccharides (LPS) on lactate dehydrogenase (LDH) activities and apoptosis in human lung bronchial epithelial (16HBE) cells

\begin{tabular}{|c|c|c|c|c|}
\hline \multirow{2}{*}{$\begin{array}{c}\text { Dose of SRM } 2786 \\
{[\mu \mathrm{g} / \mathrm{ml}]}\end{array}$} & \multicolumn{2}{|c|}{$\begin{array}{c}\text { LDH activities } \\
{[\mathrm{U} / \mathrm{l}]} \\
(\mathrm{M} \pm \mathrm{SD})^{\mathrm{a}}\end{array}$} & \multicolumn{2}{|c|}{$\begin{array}{c}\text { Apoptosis } \\
{[\%]} \\
(\mathrm{M} \pm \mathrm{SD})^{\mathrm{a}}\end{array}$} \\
\hline & $\begin{array}{l}\text { SRM } 2786 \\
\text { alone }\end{array}$ & $\begin{array}{l}\text { pretreatment } \\
\text { with LPS }\end{array}$ & $\begin{array}{l}\text { SRM } 2786 \\
\text { alone }\end{array}$ & $\begin{array}{l}\text { pretreatment } \\
\text { with LPS }\end{array}$ \\
\hline 0.00 & $62.82 \pm 3.35$ & $72.82 \pm 3.35$ & $14.70 \pm 0.53$ & $29.85 \pm 1.39^{\#}$ \\
\hline 31.25 & $94.96 \pm 4.39$ & $103.59 \pm 8.30$ & $17.86 \pm 1.33$ & $43.27 \pm 4.43^{* *, \# \#}$ \\
\hline 125.00 & $141.00 \pm 23.17^{* *}$ & $220.62 \pm 8.06^{* * \#}$ & $34.61 \pm 4.44^{* *}$ & $54.11 \pm 3.34^{* *, \# \#}$ \\
\hline 250.00 & $247.48 \pm 30.93^{* *}$ & $312.70 \pm 25.25^{* *, \#}$ & $43.05 \pm 0.65^{* *}$ & 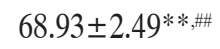 \\
\hline
\end{tabular}

a Three independent experiments.

${ }^{\#} \mathrm{p}<0.05$ - compared with cells treated with same concentration of SRM 2786 without LPS pretreatment.

$\# \#$ p $<0.01$ - compared with cells treated with same concentration of SRM 2786 without LPS pretreatment.

** $\mathrm{p}<0.01$ - compared to control cells. 
Table 2. The production of nitric oxide (NO) and reactive oxygen species (ROS) induced by standard reference material of fine particulate matter (SRM 2786) and lipopolysaccharides (LPS) in human lung bronchial epithelial (16HBE) cells

\begin{tabular}{|c|c|c|c|c|}
\hline \multirow{2}{*}{$\begin{array}{c}\text { Dose of SRM } 2786 \\
{[\mu \mathrm{g} / \mathrm{ml}]}\end{array}$} & \multicolumn{2}{|c|}{$\begin{array}{c}\text { Concentration of NO } \\
{[\mu \mathrm{mol} / \mathrm{l}]} \\
(\mathrm{M} \pm \mathrm{SD})^{\mathrm{a}}\end{array}$} & \multicolumn{2}{|c|}{$\begin{array}{l}\text { ROS level } \\
(\mathrm{M} \pm \mathrm{SD})^{\mathrm{a}}\end{array}$} \\
\hline & $\begin{array}{l}\text { SRM } 2786 \\
\text { alone }\end{array}$ & $\begin{array}{l}\text { pretreatment } \\
\text { with LPS }\end{array}$ & $\begin{array}{l}\text { SRM } 2786 \\
\text { alone }\end{array}$ & $\begin{array}{l}\text { pretreatment } \\
\text { with LPS }\end{array}$ \\
\hline 0.00 & $1.58 \pm 0.30$ & $3.16 \pm 0.91$ & $1.00 \pm 0.00$ & $1.08 \pm 0.02$ \\
\hline 31.25 & $12.08 \pm 0.36^{* *}$ & $12.17 \pm 0.98^{* *}$ & $1.06 \pm 0.03$ & $1.19 \pm 0.01^{* *, \# \#}$ \\
\hline 125.00 & $15.08 \pm 1.44^{* *}$ & $19.25 \pm 0.88^{* *, \#}$ & $1.13 \pm 0.02 *$ & $1.26 \pm 0.02 * *, \ldots$ \\
\hline 250.00 & $18.33 \pm 1.02 * *$ & $22.83 \pm 0.55^{* *, \#}$ & $1.24 \pm 0.01^{* *}$ & $1.29 \pm 0.08^{* *}$ \\
\hline
\end{tabular}

$* \mathrm{p}<0.05$ - compared to control cells.

Other explanations as in Table 1.

Significant difference was observed in Table 1.

\section{DISCUSSION}

Cytotoxicity of PM evokes increasing concerns with adverse effects on human health, especially on the respiratory system [17]. Epithelial cells act as a frontline defense against PM through physical and immunological functions. When exposed to PM, epithelial cells could induce a systemic inflammatory response synergistically with macrophage to clear inhaled particles [18]. Meanwhile, PM could also induce cell damage in epithelial cells. For instance, exposure to $\mathrm{PM}_{2.5}$ may induce apoptosis by activating the mitochondrial pathway in lung alveolar epithelial L132 cells [19]. The aim of this study has been to examine the biological activity of SRM 2786 on cell apoptosis in human bronchial epithelial $16 \mathrm{HBE}$ cells. In addition, there is now increasing evidence that the inflammation could induce epithelial cells apoptosis by mediating the production of both free radicals and cytokine [12]. Therefore, we have also sought to determine whether LPS-induced inflammation may further accelerate cell apoptosis induced by SRM 2786 stimulation.

In this research, we have found that the LDH level from the cells that are exposed to SRM 2786 significantly increases with the elevated concentrations of SRM 2786 $(31.25-125 \mu \mathrm{g} / \mathrm{ml})$. The results of Hoechst 33342/PI stain- ing have shown that SRM 2786 causes a significantly increasing apoptotic rate based on elevated concentration of SRM 2786. This phenomenon has been consistent with a former study in L132 cells [19], which has found that $\mathrm{PM}_{2.5}$ induces increase in the amount of apoptotic rate as compared to the control group.

The Bcl-2 subfamily contains anti-apoptotic proteins such as Bcl-2, which reduces cytochrome $c$ release from mitochondria into the cytosol and suppresses a downstream apoptosis program whereas the Bax subfamily contains pro-apoptotic proteins such as Bax, which promotes cytochrome $c$ release [20]. Therefore, alterations in expression of both Bcl-2 and Bax might be essential for the mitochondrial intrinsic apoptosis program. In this study, the expression of Bax significantly increases while the level of Bcl-2 significantly decreases when cells are exposed to $500 \mu \mathrm{g} / \mathrm{ml}$ of SRM 2786, indicating that SRM 2786 may induce apoptosis by increasing expression of Bax and decreasing expression of Bcl-2 and in turn activating mitochondrial apoptosis pathway.

Free radicals such as ROS and NO are known to induce oxidative stress, subsequently impairing mitochondrial function [21]. Recent studies have demonstrated that the production of ROS increases, as followed by Bax translocation, and then triggers the cell apoptosis [22]. A strong 
correlation exists between the PM content of redox active chemicals and their capability to induce oxidative stress in macrophages and bronchial epithelial cells [23]. In this study, a significant increase in the production of NO has been detected after varied concentration of SRM 2786 treatment in 16HBE cells. Meanwhile, there has been a trend in elevated ROS production in 16HBE cells treated by the lower dose of SRM 2786, and a significant increase in ROS production has been observed in $16 \mathrm{HBE}$ cells treated with the higher concentration of SRM 2786. Therefore, it is conceivable that increased cell apoptosis following SRM 2786 treatment may be partially mediated by elevated production of NO and ROS in $16 \mathrm{HBE}$ cells.

In addition, inflammation triggered by LPS could increase expression of cleaved caspase-3, and induce apoptosis of various cells, including macrophages, alveolar and bronchial epithelial cells $[12,13,24]$. However, the relationship between PM-mediated apoptosis processes and inflammation is not completely known. In this study, the results have demonstrated that in comparison with groups treated with SRM 2786 alone, LPS pretreatment remarkably decreases the cell viability of $16 \mathrm{HBE}$ cells $(125 \mu \mathrm{g} / \mathrm{ml}$ and $500 \mu \mathrm{g} / \mathrm{ml} \mathrm{SRM} \mathrm{2786),} \mathrm{together} \mathrm{with} \mathrm{increased} \mathrm{cell}$ apoptotic rate. These findings have indicated that epithelial cells are more susceptible to $\mathrm{PM}_{2.5}$ under inflammation condition.

The mechanism of apoptosis induced by inflammation remains uncertain. Xaus et al. proved that inflammation could induce macrophage apoptosis by mediating the production of both NO and TNF- $\alpha$ [24]. Sagoo et al. showed that pro-inflammatory cytokines, including TNF- $\alpha$, interferon $\gamma($ IFN- $\gamma)$, and interleukin-1 $\beta$ (IL-1 $\beta$ ) resulted in apoptosis by the generation of NO [25]. In this study, we have also observed that there is a significant increase in NO and ROS production in cells treated by both $125 \mu \mathrm{g} / \mathrm{ml}$ of SRM 2786 and LPS, as compared to groups treated with $125 \mu \mathrm{g} / \mathrm{ml}$ of SRM 2786 alone. These results suggest that pre-treatment with LPS may further promote cell apoptosis induced by SRM 2786 through free radicals-mediated pathway. Sagoo et al. have suggested that pro-inflammatory cytokines could up-regulate inducible nitric oxide synthase (iNOS), and elevate de novo production of NO [25]. However, the exact mechanism of how PM and/or inflammatory microenvironment increase the production of NO and ROS is unclear, and this issue needs to be investigated in further study.

\section{CONCLUSIONS}

In conclusion, this study shows that the cell viability, apoptotic rate, expression of $\mathrm{Bax}$ and $\mathrm{Bcl}-2$, as well as the production of NO and ROS of 16HBE cells are affected by SRM 2786 stimulation. Meanwhile, the results also illustrate that LPS pre-treatment could further aggravate the cell apoptosis post SRM 2786 stimulation, indicating that epithelial cells are more susceptible to PM under inflammation condition. Moreover, our results suggest that the free radicals-mediated oxidative stress might be the possible mechanism in SRM 2786-induced apoptosis. We report a pathway through which fine PM with LPS may induce cell apoptosis synergistically in 16HBE cells. Our findings provide the insight into the cytotoxicity of fine PM in bronchial epithelial cells and could facilitate shedding light on mechanisms underlying the development of respiratory disorders or diseases associated with fine PM-related urban air pollution.

\section{REFERENCES}

1. Choi JH, Kim JS, Kim YC, Kim YS, Chung NH, Cho MH. Comparative study of $\mathrm{PM}_{2.5}$ - and $\mathrm{PM}_{10}$ - Induced oxidative stress in rat lung epithelial cells. J Vet Sci. 2004;5(1):11-8.

2. Turner MC, Krewski D, Pope CA, 3rd, Chen Y, Gapstur SM, Thun MJ. Long-term ambient fine particulate matter air pollution and lung cancer in a large cohort of never-smokers. Am J Respir Crit Care Med. 2011;184(12):1374-81, https:// doi.org/10.1164/rccm.201106-10110C. 
3. Zhu R, Chen Y, Wu S, Deng F, Liu Y, Yao W. The relationship between particulate matter $\left(\mathrm{PM}_{10}\right)$ and hospitalizations and mortality of chronic obstructive pulmonary disease: A meta-analysis. COPD. 2013;10(3):307-15, https://doi.org/ 10.3109/15412555.2012.744962.

4. Heinrich J, Thiering E, Rzehak P, Kramer U, Hochadel M, Rauchfuss KM, et al. Long-term exposure to $\mathrm{NO}_{2}$ and $\mathrm{PM}_{10}$ and all-cause and cause-specific mortality in a prospective cohort of women. Occup Environ Med. 2013;70(3):179-86, https://doi.org/10.1136/oemed-2012-100876.

5. Knight DA, Holgate ST. The airway epithelium: Structural and functional properties in health and disease. Respirology. 2003;8(4):432-46, https://doi.org/10.1046/j.1440-18 43.2003.00493.x.

6. Hiemstra PS. Epithelial antimicrobial peptides and proteins: Their role in host defence and inflammation. Paediatr Respir Rev. 2001;2(4):306-10, https://doi.org/10.1053/prrv. 2001.0165.

7. Wang T, Wang L, Moreno-Vinasco L, Lang GD, Siegler JH, Mathew B, et al. Particulate matter air pollution disrupts endothelial cell barrier via calpain-mediated tight junction protein degradation. Part Fibre Toxicol. 2012;9:35, https:// doi.org/10.1186/1743-8977-9-35.

8. Deng X, Zhang F, Wang L, Rui W, Long F, Zhao Y, et al. Airborne fine particulate matter induces multiple cell death pathways in human lung epithelial cells. Apoptosis. 2014;19(7):1099-112, https://doi.org/10.1007/s10495-0140980-5.

9. Hetland RB, Cassee FR, Refsnes M, Schwarze PE, Lag M, Boere AJ, et al. Release of inflammatory cytokines, cell toxicity and apoptosis in epithelial lung cells after exposure to ambient air particles of different size fractions. Toxicol In Vitro. 2004;18(2):203-12, https://doi.org/10.1016/S0887-23 33(03)00142-5.

10. Gualtieri M, Longhin E, Mattioli M, Mantecca P, Tinaglia V, Mangano E, et al. Gene expression profiling of A549 cells exposed to Milan $\mathrm{PM}_{2.5}$. Toxicol Lett. 2012;209(2):136-45, https://doi.org/10.1016/j.toxlet.2011.11.015.
11. Mitkus RJ, Powell JL, Zeisler R, Squibb KS. Comparative physicochemical and biological characterization of NIST Interim Reference Material $\mathrm{PM}_{2.5}$ and SRM 1648 in human A549 and mouse RAW264.7 cells. Toxicol In Vitro. 2013;27(8):2289-98, https://doi.org/10.1016/j.tiv. 2013.09.024.

12. Comer DM, Elborn JS, Ennis M. Inflammatory and cytotoxic effects of acrolein, nicotine, acetylaldehyde and cigarette smoke extract on human nasal epithelial cells. BMC Pulm Med. 2014;14(1):32, https://doi.org/10.1186/1471-24 66-14-32.

13. Kitamura Y, Hashimoto S, Mizuta N, Kobayashi A, Kooguchi K, Fujiwara I, et al. Fas/FasL-dependent apoptosis of alveolar cells after lipopolysaccharide-induced lung injury in mice. Am J Respir Crit Care Med. 2001;163(3 Pt 1): 762-9, https://doi.org/10.1164/ajrccm.163.3.2003065.

14. National Institute of Standards and Technology. Certificate of analysis. Standard reference material 2786. Fine atmospheric particulate matter (mean particle diameter $<4 \mu \mathrm{m}$ ) [Internet]. The Institute; 2013 [cited 2013 Aug 13]. Available from: https://www-s.nist.gov/srmors/view_cert.cfm?s $\mathrm{rm}=2786$.

15. Finney SJ, Leaver SK, Evans TW, Burke-Gaffney A. Differences in lipopolysaccharide- and lipoteichoic acid-induced cytokine/chemokine expression. Intensive Care Med. 2012;38(2):324-32, https://doi.org/10.1007/s00134-011-2444-5.

16. Huo Y, Rangarajan P, Ling EA, Dheen ST. Dexamethasone inhibits the Nox-dependent ROS production via suppression of MKP-1-dependent MAPK pathways in activated microglia. BMC Neurosci. 2011;12:49, https://doi.org/10.1186/14712202-12-49.

17. Xiong Q, Ru Q, Chen L, Yue K, Tian X, Ma B, et al. Combined effects of fine particulate matter and lipopolysaccharide on apoptotic responses in NR8383 macrophages. J Toxicol Environ Health A. 2015;78(7):443-52, https://doi.org/10. 1080/15287394.2014.993490.

18. Fujii T, Hayashi S, Hogg JC, Mukae H, Suwa T, Goto Y, et al. Interaction of alveolar macrophages and airway epithelial 
cells following exposure to particulate matter produces mediators that stimulate the bone marrow. Am J Respir Cell Mol Biol. 2002;27(1):34-41, https://doi.org/10.1165/ajrcmb. 27.1.4787.

19. Dagher Z, Garcon G, Billet S, Gosset P, Ledoux F, Cour$\cot \mathrm{D}$, et al. Activation of different pathways of apoptosis by air pollution particulate matter $\left(\mathrm{PM}_{2.5}\right)$ in human epithelial lung cells (L132) in culture. Toxicology. 2006;225(1):12-24, https://doi.org/10.1016/j.tox.2006.04.038.

20. Kluck RM, Bossy-Wetzel E, Green DR, Newmeyer DD. The release of cytochrome $\mathrm{c}$ from mitochondria: A primary site for Bcl-2 regulation of apoptosis. Science. 1997;275 (5303):1132-6, https://doi.org/10.1126/science.275.5303.1132.

21. Park MY, Jeong YJ, Kang GC, Kim MH, Kim SH, Chung HJ, et al. Nitric oxide-induced apoptosis of human dental pulp cells is mediated by the mitochondria-dependent pathway. Korean J Physiol Pharmacol. 2014;18(1):25-32, https:/doi. org/10.4196/kjpp.2014.18.1.25.
22. Zhang L, Zhou L, Du J, Li M, Qian C, Cheng Y, et al. Induction of apoptosis in human multiple myeloma cell lines by ebselen via enhancing the endogenous reactive oxygen species production. Biomed Res Int. 2014;2014:696107, https:// doi.org/10.1155/2014/696107.

23. Li N, Xia T, Nel AE. The role of oxidative stress in ambient particulate matter-induced lung diseases and its implications in the toxicity of engineered nanoparticles. Free Radic Biol Med. 2008;44(9):1689-99, https://doi.org/10.1016/j.freeradbiomed.2008.01.028.

24. Xaus J, Comalada M, Valledor AF, Lloberas J, Lopez-Soriano F, Argiles JM, et al. LPS induces apoptosis in macrophages mostly through the autocrine production of TNFalpha. Blood. 2000;95(12):3823-31.

25. Sagoo P, Chan G, Larkin DF, George AJ. Inflammatory cytokines induce apoptosis of corneal endothelium through nitric oxide. Invest Ophthalmol Vis Sci. 2004;45(11):3964-73, https://doi.org/10.1167/iovs.04-0439.

This work is available in Open Access model and licensed under a Creative Commons Attribution-NonCommercial 3.0 Poland License - http://creativecommons.org/ licenses/by-nc/3.0/pl/deed.en. 